International Journal of Learning, Teaching and Educational Research

Vol. 21, No. 2, pp. 72-88, February 2022

https://doi.org/10.26803/ijlter.21.2.5

Received Dec 13, 2021; Revised Feb 11, 2022; Accepted Feb 13, 2022

\title{
Analysis of the English Language Needs of the Saudi Tourism Workforce: A First Step into Designing ESP Teaching Materials
}

\author{
Eidhah Abdullah AbdulRaheem Al-Malki \\ Foreign Languages Department, Taif University, Taif, KSA \\ Choudhary Zahid Javid* \\ Foreign Languages Department, Taif University, Taif, KSA \\ Muhammad Umar Farooq \\ English Language Center, Taif University, Taif, Saudi Arabia \\ Ghazi Fahad Algethami \\ Foreign Languages Department, Taif University, Taif, KSA \\ Adel Awadh Al-Harthi \\ Foreign Languages Department, Taif University, Taif, KSA
}

\begin{abstract}
Communication skills are extremely important for the tourism industry; they form an integral part of most tourism activities. Using English, as the international lingua franca, is an essential part of these skills, especially for international tourism. Saudi Vision 2030 places a high importance on international tourism as a driving force for economic growth. Since the inception of the Saudi Vision 2030, the tourism industry in Saudi Arabia, along with its workforce, has been growing substantially. Therefore, designing English language teaching materials for the tourism industry workforce in Saudi Arabia is a necessity. The current study firstly aimed to analyze the English language communicative needs of the Saudi tourism workforce, and then propose an English for Specific Purposes (ESP) model for teaching English based on their needs. A nation-wide survey was designed and distributed to sixty-two male and fifteen female workers serving in the Saudi tourism industry to determine their English language communicative needs. Listening and speaking were found to be highly important to their profession, in particular understanding instructions and requirements and providing details about touristic attractions. Reading and vocabulary were found more important than writing and
\end{abstract}




\begin{abstract}
grammatical accuracy. The study concludes with a proposal of an ESP teaching model to meet the English language communicative needs of the tourism workforce in Saudi Arabia.
\end{abstract}

Keywords: language teaching; ESP; needs analysis; Communication; Saudi; Tourism

\title{
1. Introduction
}

Tourism is a major source of income for many national economies (Fujita, 2020). It is "a social, cultural and economic phenomenon which entails the movement of people to countries or places outside their usual environment for personal or business/professional purposes" (United Nation World Tourism Organization, n.d.: www.unwto.org). The United Nations World Tourism Organization predicts that by 2030 there will be more than 1.8 billion international tourists. This booming increase in the number of people travelling for touristic purposes has created an industry for travelling and tourism agencies. These agencies' work provides a wide array of services to tourists. These services include providing a guide who accompanies travelers and tourists to attraction sites. Communication between the agencies and guides on one hand, and the travelers or tourists on the other is inevitable. For this reason, communication skills, including language proficiency, are vital for the work of tourism guides and agencies (Ap \& Wong, 2001; Bobanovic \& Grzinic, 2011; Dhiman, 2012). Much of the communication takes place between people who do not share the same first language (Prachanant, 2012).

English is the global lingua franca, and it is widely used for communication between people who do not share the same language background (Crystal, 2003). In tourism, English is the most widely used language for communication with international tourists; a good command of English is certainly an added value for any worker in the tourism industry, regardless of their position (Blue \& Harun, 2003; Gonzalez-Pastor, 2013). Therefore, any national tourism industry interested in attracting international tourists for any purpose should prioritize equipping its workforce with a good command of English specific to tourism (Al-Khatib, 2005; Dhiman, 2012; Kim et al., 2017). In fact, in addition to the overall proficiency in English, there is a growing need for equipping professionals working or planning to work in the tourism industry with the communicative English skills needed for their profession, such as providing or asking for information (Blue \& Harun, 2003; Bobanovic \& Grzinic, 2011; Yasmin et al., 2016).

Teaching English for specific or occupational purposes is not new. In fact, it is by now a well-established language teaching approach which focuses on satisfying the specific needs of English learners (Anthony, 2018). A stakeholders' needs analysis is a prerequisite for developing curriculum or materials for teaching English for specific or occupational purposes. A few studies have examined the English language communicative needs in the tourism profession in various contexts (Al-Khatib, 2005; Blue \& Harun, 2003; Bobanovic \& Grzinic, 2011; Crystal, 2003; Fujita, 2020; Rahim \& Tazijan, 2011). To tailor the teaching materials to meet the needs of a specific population, it is necessary to consider the learners' local context (Anthony, 2018). 
Saudi Arabia has launched an ambitious campaign (Vision 2030) to transform and diversify the economy. It is currently building mega touristic cities (for example, Neom and the Red Sea project) and investing in other large projects in the tourism industry (Kane \& Al-Khudair, 2021). Two of the key components of this vision are increasing the investment in tourism and allowing and facilitating the entrance of international tourists and visitors. For the first time in recent years Saudi Arabia has issued tourist visas for international visitors. These can be issued online and in a matter of a few days. The ultimate goal is to be a regional and international hub for international tourists. For this reason, there has been a growing interest in offering training courses and qualifications in tourism-related fields. Now there are even colleges specializing in tourism and hospitality (for example, https://www.tvtc.gov.sa/index-en.html). This growth in both tourism services and tourism training is unprecedented in the history of Saudi Arabia.

The current study seeks to provide an insight into the English language communicative needs of the Saudi tourism workforce considering the aforementioned importance of the English language to the tourism industry and the new place for tourism in Saudi Arabia. This is a first step in developing English language teaching materials tailored specifically to meet the needs of the Saudi tourism workforce. The researchers are not aware of any other study that has examined the English language communicative needs of the Saudi tourism workforce. The current study concludes by suggesting a model for teaching ESP for the Saudi tourism workforce based on the needs analysis results.

\section{Research Questions}

1. How important is the English language for the Saudi tourism workforce?

2. How important are various English language skills for the Saudi tourism workforce?

3. How important are various English language sub-skills for the Saudi tourism workforce?

\section{Literature Review}

\subsection{Language Needs Analysis}

ESP is directed towards serving the language communicative needs of a specific discourse community (Brown, 2009; Swales, 1990). Collecting and analyzing information about the language needs of a specific community is the first step necessary for developing ESP courses or materials for that specific community (Anthony, 2018; Maswana \& Tajino, 2020). A needs analysis leads to the development of "a defensible curriculum" which "satisfies the language learning and teaching requirements of the students and teachers within the context of particular institution(s) involved" (Brown, 2009, p. 269). Hutchinson and Waters (1987) introduced three types of language needs: i) Necessities: what the learners must know; ii) Lacks: the difference between what the learners know and what they need to know, and iii) Wants: what the learners want to know. The current study focuses on the third type (wants) because there are no previous studies examining the needs or language proficiency of the Saudi tourism workforce. Several studies have examined the language needs of professionals working in the tourism industry in other countries (Al-Khatib, 2005; Blue \& Harun, 2003; Bobanovic \& Grzinic, 2011; Davies, 2000; Prachanant, 2012; Rahim \& Tazijan, 2011; Yasmin et al., 2016). However, needs 
analysis should focus on the needs of a specific community of learners and their learning context (Anthony, 2018; Maswana \& Tajino, 2020). In fact, Blue and Harun (2003) mentioned that the language used in hospitality is culturally bound.

\subsection{Needs Analysis Model}

It is reported that a comprehensive needs analysis would help ESP researchers and practitioners to identify the learners' needs efficiently (Dudley-Evans \& St. John, 1998; Flowerdew, 2013; Ghulamullah et al., 2011; Khan et al., 2011; Songhori, 2008). There are two major aspects in any needs analysis model: present situation analysis (PSA) and target situation analysis (TSA). Javid and Khan (2013) have reported that TSA covers wants, means, and the subjective needs of learners that may affect the way they learn. It basically aims to record the learners' language needs to communicate with international visitors. It also documents their qualifications, experience in the field, and cultural information, among others. On the other hand, PSA attempts to investigate the learners' current proficiency in various language skills and sub-skills which determines the assessment of their difficulties in English (Kim et al., 2017; Liu \& Zhang, 2020). PSA includes pedagogic needs as well as the learners' background knowledge and English proficiency (Hutchinson \& Waters, 1987; Yundayani, 2018). Both approaches help to identify the learners' present knowledge of English, their deficiencies or lack in using English, and their needs (Yundayani, 2018). In addition, some needs analysis models have included the learners' interests and attitudes, and their learning styles as well (Cohen \& Macaro, 2007; Bidabadi \& Yamat, 2010). This will help researchers and material designers select suitable resources and strategies to help their learners improve their language communication skills effectively (Cohen \& Macaro, 2007) and develop effective learning strategies (Horwitz, 2012). The second major factor in designing a needs analysis model is motivation, both intrinsic and extrinsic (Javid et al., 2012). The third factor is communicative needs, keeping in mind local culture and social values. This will help the learners to communicate better in the target situation. This is similar to target situation analysis, register analysis, discourse analysis, and genre analysis as defined in other needs analysis models (Dudley-Evans \& St. John, 1998; West, 1994).

\subsection{Previous Studies}

The high level of importance of ESP for tourism generated a considerable amount of research examining the English language used in various tourism sectors, which includes the study of its linguistic and communicative aspects and the communicative needs of its workforce (Fujita, 2020). For example, Blue and Harun (2003) conducted a case study which highlighted the distinctive aspects of the language used in the hospitality sector in the UK. They recommended the design of ESP training courses for personnel working in the hospitality sector. Those that examined the language needs of the tourism industry workforce which are relevant to the current study are discussed as follows.

One of the earliest studies that examined the language needs of the tourism industry is that of Davies (2000). In the UK context, her results showed that speaking a foreign language was a clear advantage for those working in the tourism sectors. In addition, it was found that listening and speaking skills were of high importance to her participants. In another European context, Bobanovic and Grzinic (2011) ran a questionnaire to determine the English language communicative needs of tourism 
students and employees in Croatia. Approximately $70 \%$ of the employees surveyed mentioned that they needed reading and writing for business correspondence. Only $10 \%$ of them also believed that their speaking skills were poor. Accent, speaking fast, and idiomatic English were found to be among the obstacles the employees faced when they tried to comprehend the spoken language.

In the Asian context, Prachanant (2012) surveyed the English language communicative needs of 40 employees working in international tourism companies in Thailand. The results showed that, for the surveyed employees, speaking and listening were more important than reading and writing. Providing information and assistance were found to be the most needed communicative functions. Accented and fast speech and inadequate vocabulary were among the communication difficulties they faced during their communications. Rahim and Tazijan (2011) asked a number of managers and interns working in hotels in Penang in Malaysia about their oral communication needs. Answering customers' enquires and requests were found to be highly relevant and important for their profession. Yasmin et al. (2016) explored the English language needs of 50 students and employees in the hospitality sector in Pakistan. Although listening and speaking skills were the most frequently used skills by professionals in the sector, reading and writing were also found to be highly important for a few activities. Listening to requests, complaints and responding to calls and enquires are among the most important listening and speaking activities for their participants. In addition, reading and responding to written complaints and requests were among the most valued language skills by the surveyed employees. Fujita (2020) analyzed the English language needs of those who work in the tourism industry in Japan. Listening and speaking skills were rated as the most necessary skills. Listening to fast and accented English was among the difficulties faced by the participants when they were involved in communication with international tourists.

In a similar context to the current study, Al-Khatib (2005) examined the language needs of 15 bilingual (Arabic-English) senior staff working in the tourism industry in Jordan. In addition to acknowledging the need for English in their jobs, most of them mentioned that they needed English for communication purposes, which is in demand in an industry where there is much interaction between staff and clients. At least $27 \%$ of them also mentioned that they used English for correspondence purposes. Regarding their specific English language needs, most of the participants mentioned that they needed specialized vocabulary, as well as speaking and writing skills. The need for speaking skills and specialized vocabulary is to be expected in the tourism industry; however, the need for writing skill may be the result of the specific needs of the participants because of their senior positions.

\section{Method}

The aim of the current research is to examine the English language needs of the Saudi tourism workforce, and to propose a model for teaching English for current or future employees in the tourism industry in Saudi Arabia. Therefore, a quantitative crosssectional survey design was deemed appropriate for the current study. A five-point Likert scale was designed to collect data from employees working in various tourism sectors across Saudi Arabia. 


\subsection{Participants}

Saudi Arabia is an emerging tourist destination, and the number of professionals working in the tourism industry has been increasing substantially. A convenience random sampling method was used to collect data from 77 professionals working in various tourism sectors, such as hotel managers, tour guides, academics, and public officials in governmental tourism offices. In the first half of 2021 the participants were contacted through various means, such as the telephone and email. Owing to the current international Covid-19 pandemic, it was extremely difficult to meet the participants in person as most of the offices and hotels were closed.

\subsection{Research Instrument}

The survey consisted of 49 items. The first ten items were designed to elicit background information, such as educational and professional backgrounds, and the rest examined their English language communicative needs as professionals working in the tourism industry. Items 11 and 12 asked the participants about the importance of English for their jobs and the order of importance of the major language skills for tourism. The items about the language needs were presented to the participants in a five-point Likert scale with five options: (5) extremely important, (4) important, (3) moderately important, (2) slightly important, and (1) least important. The items presented for rating asked focused on the degree of importance of various language skills presented under the major language skill types: listening, speaking, reading, writing, vocabulary and grammar.

The draft version constructed by the researchers was modified and revised following the suggestions of two experienced English language instructors and one statistics expert to ensure the validity of the survey. A pilot study was subsequently carried out to test the reliability and suitability of the questionnaire for the aim of the study and the appropriateness of the language used. Ten participants were requested to fill out the questionnaire, to provide feedback on the content and wording, and to provide suggestions on items that should be added or excluded. Lastly, the final draft of the questionnaire was revised and then administered to the target tourism employees. To assure the reliability of the questionnaire, a Cronbach alpha coefficient was calculated, and the result revealed a high coefficient at .9538, which demonstrates the high level of consistency between the respondents' answers. The above steps were taken to assure the validity and reliability of the instrument to assist in reaching sound conclusions and implications for the English language needs of the tourism workforce in Saudi Arabia.

Descriptive analysis was run to generate frequencies and percentages to determine the importance of the English language and its various skills and sub-skills for the Saudi tourism workforce.

\subsection{Ethical Considerations}

The researchers submitted the final version of the questionnaire to the Research Ethics Committee of Taif University which allotted permission number 42-043 to the instrument. Furthermore, the vice-president of Taif University issued request letters to the Department of Tourism, Taif; the Department of Tourism, Jeddah; the College of Tourism and Hospitality, Taif; and the College of Tourism and Hospitality, Madinah to facilitate data collection from the Saudi tourism workforce. 


\section{Results}

\subsection{Demographic Information}

The nature of the current research necessitated knowledge of the participants' demographic information, such as qualifications, experience, and other relevant information. This may provide a snapshot of the demographics of people working in the tourism industry in Saudi Arabia, and may be of use to policy makers and designers of language teaching materials.

The majority of the participants were males $(79 \%)$ with female participants making up $21 \%$. In fact, the number of females working in the tourism industry has been growing substantially since the inception of Vision 2030 (World Tourism Organization, 2020). The age range of the participants was wide, ranging from 18 to 64 years old. A total of $43 \%$ were in the age group of 35-44 years old. A sizable number of young people $(13 \%)$ were among the participants, which indicates that the tourism industry in Saudi Arabia is attracting young people as well. This may also indicate that the industry is in fact growing. The rest of the participants $(21 \%$ and $15 \%)$ were from the age groups of 25-34 and 45-54 years, respectively.

With regard to the participants' years of experience in the tourism industry, 38\% of them had between six to 15 years of experience while $40 \%$ of the participants had less than five years of experience. This is in line with the age and gender information, which clearly indicates the growing nature of the tourism industry and the effectiveness of the governmental measures to promote tourism in light of its Vision 2030.

Saudi Arabia is a large country geographically; however, the density of population is confined to a few cities across the Kingdom. The majority of the participants $(23 \%)$ were from the capital, Riyadh. The two holy Islamic cities were next in terms of the workplace of the participants, namely Almadinah (19\%) and Makkah (13\%). Finally, $10 \%$ of the participants were from Dammam and 9\% were from Taif, which are two of the major touristic destinations in Saudi Arabia.

The majority of the participants had a bachelor's degree. They have learned English as a foreign language in schools and at university level. A total of 22 participants reported that they had a masters' degree while $70 \%$ also mentioned that they had a professional qualification in tourism. More than half of the participants $(58 \%)$ mentioned that they had an English language proficiency test certificate. This clearly shows how important proficiency in English is to the tourism industry.

\subsection{Language Communicative Needs}

The data generated from the participants' responses towards the importance of the English language in effectively communicating with international tourists, and the significance of the various language skills and sub-skills are presented in terms of percentages in the following tables. 


\subsubsection{English Language}

Table 1: English language needs

\begin{tabular}{|c|c|c|c|c|} 
No & Rank & Frequency & Percent & Cumulative percent \\
\hline $\mathbf{1}$ & Extremely important & 51 & 66.2 & 66.2 \\
\hline $\mathbf{2}$ & Important & 17 & 22.1 & 88.3 \\
\hline $\mathbf{3}$ & Somewhat & 2 & 2.6 & 90.9 \\
& important & & & \\
\hline $\mathbf{4}$ & Least important & 4 & 5.2 & 96.1 \\
\hline $\mathbf{5}$ & Not important & 3 & 3.9 & 100 \\
\hline $\mathbf{6}$ & Total & 77 & 100.0 & 100.0 \\
\hline
\end{tabular}

Table 1 presents responses related to the importance of the English language. The vast majority of the participants recognized the importance of English to their profession, namely $66.23 \%$ acknowledged its extreme importance, and $22.1 \%$ ranked it important. Extremely low preferences were assigned to the other three options. This is expected as recent years have seen an influx of international tourists in Saudi Arabia, which precipitated the need for the English language to be able to communicate with international tourists who do not speak Arabic.

\subsubsection{Language skills}

Table 2: Language skills needs

\begin{tabular}{|c|c|c|c|c|}
\hline No & Language Skills & Frequency & Percent & Cumulative percent \\
\hline $\mathbf{1}$ & $\begin{array}{c}\text { Speaking and } \\
\text { Pronunciation }\end{array}$ & 50 & 64.9 & 64.9 \\
\hline $\mathbf{2}$ & Listening Skills & 10 & 13.0 & 77.9 \\
\hline $\mathbf{3}$ & Tourism Vocabulary & 7 & 9.1 & 87 \\
\hline $\mathbf{4}$ & Writing Skills & 4 & 5.2 & 92.2 \\
\hline $\mathbf{5}$ & Reading Skills & 3 & 3.9 & 96.1 \\
\hline $\mathbf{6}$ & Grammar & 3 & 3.9 & 100 \\
\hline $\mathbf{7}$ & Total & 77 & 100.0 & \\
\hline
\end{tabular}

Table 2 details the responses of the participants regarding the importance of the various language skills in discharging their professional responsibilities in the field of tourism. A total of $64.9 \%$ of the participants considered speaking and pronunciation as the most important skills needed for their jobs. Other skills were found to be important to lesser degrees, namely listening (13\%), vocabulary $(9.1 \%)$, writing $(5.2 \%)$, reading $(3.9 \%)$ and grammar $(3.9 \%)$. This is expected as the communication between tourism workers and international tourists is largely verbal in nature.

The following tables report on the results of the survey items that examined the importance of the various language communicative skills for the tourism industry in Saudi Arabia. They are presented according to the main language skills: listening, speaking, reading, writing and grammar and vocabulary. The results are presented through descriptive analysis; therefore a higher mean denotes the participants' preference. The data indicate that the vast majority of the participants assigned 'extremely important' or 'important' to all sub-skills of English language skills with 
negligible preferences for 'slightly important' or 'least important' as they considered all these sub-skills important for their profession.

\subsubsection{Listening}

Table 3: Listening needs

\begin{tabular}{|c|l|c|c|c|c|c|c|}
\hline No & \multicolumn{1}{|c|}{ Questionnaire item } & n & range & Min & max & mean & SD \\
\hline $\mathbf{1}$ & Document personal details & 77 & 4.00 & 1.00 & 5.00 & 4.4026 & .84697 \\
\hline $\mathbf{2}$ & Understand requirements & 77 & 1.00 & 4.00 & 5.00 & 4.9091 & .28936 \\
\hline $\mathbf{3}$ & Understand instructions & 77 & 1.00 & 4.00 & 5.00 & 4.8571 & .35222 \\
\hline $\mathbf{4}$ & Understand complaints & 77 & 1.00 & 4.00 & 5.00 & 4.8442 & .36509 \\
\hline $\mathbf{5}$ & Respond to phone calls & 77 & 2.00 & 3.00 & 5.00 & 4.7662 & .48385 \\
\hline $\mathbf{6}$ & Understand English slang & 77 & 3.00 & 2.00 & 5.00 & 4.2597 & .81761 \\
\hline $\mathbf{7}$ & Record feedback and suggestions & 77 & 3.00 & 2.00 & 5.00 & 4.4805 & .68076 \\
\hline $\mathbf{8}$ & Understand major accents & 77 & 4.00 & 1.00 & 5.00 & 4.1429 & 1.00935 \\
\hline
\end{tabular}

Table 3 presents the responses of the participants related to the importance of the various sub-skills of listening in the Saudi tourism market. The participants rated the importance of listening sub-skills as follows: understanding requirements (4.909), understanding instructions (4.857), understanding complaints (4.844), and responding to phone calls (4.766). This is to be expected given the nature of the services the tourism industry provides to its customers. Tourists have specific requirements regarding rooms, food, and facilities, among others; therefore, it is imperative that their requirements and instructions are understood perfectly, and at the same time that complaints, if any, are comprehended and resolved. Also, they have to attend to phone calls to be able to give efficient guidance to tourists regarding their plans and facilities. Other important aspects were documenting personal details (4.402) and recording feedback and suggestions (4.48). The least important aspects of the listening skills were understanding English slang and major accents (4.259 and 4.142). The results generally indicate that the immediate response to customers' requests and requirements are highly important to the tourism workforce in Saudi Arabia. Standard deviation (SD) values suggest that for most preferred items, inter-rater differences are marginal.

\subsubsection{Speaking and Pronunciation}

Table 4: Speaking and pronunciation needs

\begin{tabular}{|c|c|c|c|c|c|c|c|}
\hline No & Questionnaire item & $\mathbf{N}$ & range & $\min$ & $\max$ & mean & SD \\
\hline 1 & Introduce yourself & 77 & 3.00 & 2.00 & 5.00 & 4.6753 & 67749 \\
\hline 2 & Greet and bid farewell & 77 & 2.00 & 3.00 & 5.00 & 4.7922 & .46841 \\
\hline 3 & Provide details about attraction & 77 & 3.00 & 2.00 & 5.00 & 4.7662 & .51032 \\
\hline 4 & 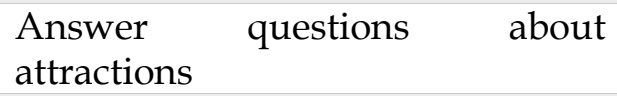 & 77 & 1.00 & 4.00 & 5.00 & 4.8052 & .39865 \\
\hline 5 & Provide required information & 77 & 3.00 & 2.00 & 5.00 & 4.7143 & .53452 \\
\hline 6 & Describe diagrams and graphs & 77 & 4.00 & 1.00 & 5.00 & 4.0130 & 1.03229 \\
\hline 7 & $\begin{array}{l}\text { Make apologies or explain the } \\
\text { reason }\end{array}$ & 77 & 3.00 & 2.00 & 5.00 & 4.5584 & .69762 \\
\hline 8 & Guide and provide directions & 77 & 3.00 & 2.00 & 5.00 & 4.5714 & 63719 \\
\hline 9 & Provide information regarding the & 77 & 4.00 & 1.00 & 5.00 & 4.4545 & .85140 \\
\hline
\end{tabular}


culture and social norms

\begin{tabular}{l|l|l|l|l|l|l|l|}
10 & Explain the financial packages & 77 & 4.00 & 1.00 & 5.00 & 4.0260 & 1.09993
\end{tabular}

\begin{tabular}{ll|l|l|l|l|l|l|}
11 & Ask about tourists' needs & 77 & 4.00 & 1.00 & 5.00 & 4.5974 & .74798 \\
\hline
\end{tabular}

\begin{tabular}{l|l|l|l|l|l|l|l|l|}
12 & Use appropriate language for & 77 & 4.00 & 1.00 & 5.00 & 4.3506 & .88505 \\
\hline
\end{tabular}

accepting or refusing requests

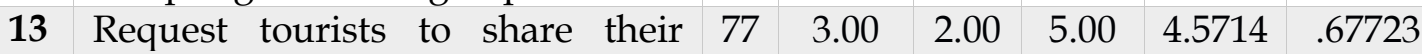

feedback/suggestions

\begin{tabular}{ll|l|l|l|l|l|l}
14 & Produce comprehensible speech & 77 & 4.00 & 1.00 & 5.00 & 4.3117 & .96327
\end{tabular} sounds (sounds, stress, rhythm, and intonation)

The data presented in Table 4 show that the participants have considered various subskills of speaking and pronunciation needs as extremely important in discharging their responsibilities in various fields of the Saudi tourism industry. The most important aspects of the speaking skills were answering questions about attractions (4.805), greeting and bidding farewell (4.792), providing details about attractions (4.766), introducing oneself (4.675), providing the required information about attractions (4.714), and asking about tourists' needs (4.597). The results reflect the type of interaction that takes place between tourism workers and tourists, which includes reception, information about attractions and answering questions. Providing guidance and directions and requesting tourists to share their feedback or suggestions as well as apologizing were found to be less important (4.571 and 4.558, respectively). The importance of ratings of other aspects of speaking include using appropriate language for accepting or refusing tourists' requests (4.35), producing comprehensible speech: sounds, stress, rhythm, and intonation (4.311), explaining financial packages (4.026) and describing diagrams and graphs at tourist attractions (4.013). The SD values for all the items denote the participants' agreement regarding the significance of the various sub-skills of this category.

\subsubsection{Reading}

Table 5: Reading needs

\begin{tabular}{|c|l|c|c|c|c|c|c|}
\hline No & \multicolumn{1}{|c|}{ Questionnaire item } & $\mathbf{n}$ & range & Min & max & mean & SD \\
\hline $\mathbf{1}$ & $\begin{array}{l}\text { Understand social media } \\
\text { messages of tourists }\end{array}$ & 77 & 3.00 & 2.00 & 5.00 & 4.4416 & .76937 \\
\hline $\mathbf{2}$ & $\begin{array}{l}\text { Understand emails of tourists } \\
\mathbf{3}\end{array}$ & 77 & 2.00 & 3.00 & 5.00 & 4.6623 & .55275 \\
\hline & $\begin{array}{l}\text { Understand requests, plans and } \\
\text { queries of tourists }\end{array}$ & 77 & 2.00 & 3.00 & 5.00 & 4.6234 & .58577 \\
\hline $\mathbf{4}$ & $\begin{array}{l}\text { Understand brochures at tourist } \\
\text { attractions }\end{array}$ & 77 & 2.00 & 3.00 & 5.00 & 4.6234 & .58577 \\
\hline $\mathbf{5}$ & $\begin{array}{l}\text { Understand signs, rules and } \\
\text { notices at tourist attractions }\end{array}$ & 77 & 3.00 & 2.00 & 5.00 & 4.6234 & .64968 \\
\hline $\mathbf{6}$ & \begin{tabular}{l} 
Feedback from tourists \\
\hline
\end{tabular} & 77 & 2.00 & 3.00 & 5.00 & 4.5455 & .63960 \\
\hline
\end{tabular}

Understanding tourists' emails received the highest importance rating (4.6) by the participants. The participants assigned the same mean of 4.6 to other items, namely understanding requests, plans and queries of tourists, understanding brochures at tourists' attraction, and understanding signs, rules and notices at tourist attractions. The least rated reading sub-skills were reading feedback from tourists (4.545) and 
understanding social media messages of tourists (4.441). It is clear that reading skills are important for the participants, but not to the same extent as speaking and listening. An interesting finding is that the participants are in agreement with each other as indicated by the low SD for all items.

\subsubsection{Writing}

Table 6: Writing needs

\begin{tabular}{|c|c|c|c|c|c|c|c|}
\hline No & Questionnaire item & n & range & Min & $\max$ & mean & SD \\
\hline 1 & $\begin{array}{l}\text { Write messages and emails to } \\
\text { tourists }\end{array}$ & 77 & 4.00 & 1.00 & 5.00 & 4.1429 & .92785 \\
\hline 2 & Respond to tourists' queries & 77 & 3.00 & 2.00 & 5.00 & 4.3117 & .84697 \\
\hline 3 & $\begin{array}{l}\text { Take notes while talking to } \\
\text { tourists }\end{array}$ & 77 & 3.00 & 2.00 & 5.00 & 4.2208 & .89771 \\
\hline 4 & $\begin{array}{l}\text { Write instructions about tourist } \\
\text { attractions }\end{array}$ & 77 & 3.00 & 2.00 & 5.00 & 4.3377 & .80476 \\
\hline 5 & $\begin{array}{l}\text { Write description of tourist } \\
\text { attractions }\end{array}$ & 77 & 3.00 & 2.00 & 5.00 & 4.3247 & 90962 \\
\hline 6 & Write reports on tourist attractions & 77 & 4.00 & 1.00 & 5.00 & 58 & .97421 \\
\hline 7 & $\begin{array}{l}\text { Write proposals for improvement } \\
\text { in tourism marketing }\end{array}$ & 77 & 4.00 & 1.00 & 5.00 & 4.0649 & 1.00443 \\
\hline
\end{tabular}

Writing did not receive the same high ratings as did the other skills; however, all items received a reasonably high mean value of more than 4 . This may indicate that writing is not a priority for many of the workers in the tourism industry. The writing skills were rated as follows: writing instructions about tourists' attractions (4.337), writing descriptions of tourist attractions (4.324), responding to tourists' queries (4.31), taking notes while talking to tourists (4.22), writing reports on tourist attractions (4.155), writing messages and emails to tourists (4.142), and writing proposals for the improvement of tourism marketing (4.064).

\subsubsection{Vocabulary and Grammar}

Table 7: Vocabulary and grammar

\begin{tabular}{|c|l|c|c|c|c|c|c|}
$\mathbf{N}$ No & \multicolumn{1}{|c|}{ Questionnaire item } & n & range & Min & max & mean & SD \\
\hline $\mathbf{1}$ & $\begin{array}{l}\text { Use specific vocabulary related to } \\
\text { tourism }\end{array}$ & 77 & 2.00 & 3.00 & 5.00 & 4.5065 & .66141 \\
\hline $\mathbf{2}$ & $\begin{array}{l}\text { Use appropriate language } \\
\text { structure for communication }\end{array}$ & 77 & 3.00 & 2.00 & 5.00 & 4.3506 & .73924 \\
\hline
\end{tabular}

Vocabulary was rated as more important than grammar. It was rated as extremely important with a mean rating of 4.506, while using appropriate grammar was also rated as important with a mean rating of 4.35 .

\section{Discussion}

The current study sought to address an urgent issue in the teaching of English language in Saudi Arabia. It aimed to explore the English language communicative needs of the Saudi tourism workforce, and to propose a teaching model for ESP tourism in Saudi Arabia. To this end, a sample of 77 people working in various 
tourism sectors in Saudi Arabia were approached and requested to complete a survey examining the importance of several communicative language skills related to the main language skills: listening, speaking and pronunciation, reading, writing and vocabulary and grammar.

In line with previous studies (for example, those of Al-Khatib, 2005; Harun \& Blue, 2003), most of the participants mentioned that English language is highly important for their jobs. They ordered the importance of the main English language skills as follows: Speaking and pronunciation, listening, tourism vocabulary, writing, reading and grammar. This finding is in line with the language needs analysis conducted in other contexts (in the UK, Japan, Thailand and Pakistan in studies by Davies, 2000; Fujita, 2020; Prachanant, 2012; Yasmin et al., 2016). On the other hand, the participants in a study byAl-Khatib (2005) mentioned that they needed specialized vocabulary and writing owing to the nature of their supervisory jobs. In addition, Bobanovic and Grzinic (2011) mentioned that 70\% of their participants needed reading and writing. This is probably owing to the fact that their participants were students and officials working in tourism agencies.

These findings show that a customized ESP for a specific context is necessary. It supports the initial premises on which the language needs analysis was built (Afzali \& Rezapoorian, 2014). The participants in the current study were from diverse professional backgrounds; therefore, it is possible that writing and reading skills for governmental officials and workers in supervisory roles are more important than speaking and listening skills. It was not possible to run an analysis by specific professions in the current study for two reasons. First, dividing the participants into groups based on the specific nature of their job within the tourism industry would yield a very small number of participants in each group, which would make generalization of the same population untenable. Second, the focus of the current study is on the population of the Saudi workforce involved in the tourism industry in general. The main finding of the current study was expected as the need for speaking and listening skills reflects the nature of the verbal interaction that takes place between workers and customers or tourists.

With regard to the listening skills, understanding requirements, complaints, instructions and phone calls were considered to be of high importance for the participants. This result is similar to the result found by Rahim and Tazijan (2011) and Yasmin et al. (2016) whose participants were working in the hospitality business. Although accented and fast speech were among the obstacles faced by the participants in studies by Bobanovic and Grzinic (2011) and Fujita (2020), the participants in the current study did not place a high level of importance on understanding the major English accents. Greeting and bidding farewell and providing information and answering questions about attractions were rated as highly important speaking skills by the participants in the current study. This is in line with the national efforts towards the introduction of heritage sites and attractions to international tourists. This finding is supported by the finding regarding the writing and reading skills in which the participants also considered writing and reading descriptions of tourist attractions as highly important. Similar to the Al-Khatib (2005) study, the participants also mentioned that using vocabulary specific to tourism was important. 


\section{Conclusion}

The current study ran an analysis of the English language communicative needs of the Saudi tourism workforce serving in various sectors of the Saudi tourism industry. It specified the importance of English language and various language communicative skills for professionals working in this industry. The needs analysis is a first step towards developing customized English language learning materials in an attempt to meet the specific needs of this rapidly growing community. The results of this investigation reveal that English language proficiency is extremely important for the Saudi workforce to communicate successfully with both national and international tourists. The study also revealed that speaking skills are the most important skill in this regard as most of the time the Saudi tourism workforce need to communicate verbally with the tourists to address to their needs. Reasonably high preferences were assigned to other language skills as well. The results related to the significance of various language sub-skills are also in line with the participants' high level of preference for speaking skills. The other most needed sub-skills were listening and reading skills. This is evidence that the participants of this survey understood and highlighted the significance of listening and reading sub-skills to maintain effective communication with tourists. The lowest mean values were recorded for vocabulary, grammar and writing sub-skills, signifying their respective significance.

The results of this investigation strongly suggest that the Saudi tourism workforce studying at colleges of tourism and hospitality situated in various regions of the KSA should be taught tailor-made courses based on their identified PSA instead of using commercial English language teaching materials. Furthermore, it is also necessary that on-the-job training courses need to be provided for the Saudi tourism workforce serving in various tourism sectors to augment their communicative skills. Therefore, the following model is proposed as an initial step for developing English language teaching materials, programs or courses.

\subsection{A Customized English for Tourism Marketing Model}

This study has suggested a model based on the results of this investigation and much previous research in the field following a pragmatic approach based on the fact that individual knowledge is grounded in individual experience. For a needs analysis, the Saudis working in tourism marketing were contacted through the ministry, institutions, offices, and personal contacts to provide their feedback on the survey as discussed above. This enabled the researchers with an opportunity to gather the necessary amount of information to obtain an understanding of the context of Saudi tourism marketing. The following customized model is suggested for the Saudi tourism workforce. 




Figure 6: A customized model for Saudi workforce working in tourism marketing

This customized model for the Saudi workforce in tourism marketing places the learners in the center and suggests four areas: i) PSA, ii) motivation (intrinsic), iii) communicative needs, and iv) motivation (extrinsic). Although previous studies focused on a wide range of specialized occupational contexts (Kim, 2013; Mohammadi \& Mousavi, 2013) and some were conducted in academic contexts (Rostami \& Zafarghandi, 2014; Shing \& Sim, 2011), they failed to investigate the needs in local and cultural contexts. Therefore, the customized model includes motivation (intrinsic and extrinsic) as well as learning styles.

Based on an analysis of the data and findings of this study and insights from previous research, it can be concluded that the customized model 'English for Tourism Marketing' will help the government officials, material designers and institutions to prepare courses and materials for the Saudi workforce in the field of tourism industry to improve their language skills while communicating with the international visitors in English.

Author Contributions: All authors contributed to the various parts of the current research, and the order of the authors reflects the weight of their contributions.

Funding: This research was funded by the Deanship of Scientific Research, Taif University, Group Project Grant, 1-441-94.

Institutional Review Board Statement: The research was approved by the Research Ethical Committee at Taif University (Decision: 42-043).

Informed Consent Statement: Informed consent was obtained from all participants involved in the study. 
Data Availability Statement: Data are available from the first author upon request.

Acknowledgments: Grateful thanks are extended to the Taif University for funding the current research.

Conflicts of Interest: The authors declare no conflict of interest.

\section{References}

Afzali, K., \& Rezapoorian, D. (2014). Pragmatic aspects of English for tourism coursebooks and ESL learners' pragmatic needs: A speech act theory perspective. Procedia - Social and Behavioral Sciences, 98, 52-59. https://doi.org/10.1016/j.sbspro.2014.03.388

Al-Khatib, M. (2005). English in the workplace: An analysis of the communication needs of tourism and banking personnel. Asian EFL Journal, 7, 174-94. https://www.asian-efljournal.com/volume-7-issue-2/index.htm

Anthony, L. (2018). Introducing English for specific purposes. Routledge.

Ap, J., \& Wong, K. F. (2001). Case study on tour guiding: Professionalism, issues and problems. Tourism Management,22, 551-563. https:/ / doi.org/10.1016/S0261-5177(01)00013-9

Bidabadi, F. S., \& Yamat, H. (2010). Learning style preferences by Iranian EFL freshman university students. Procedia - Social and Behavioral Sciences,7, 219-226. https://cyberleninka.org/article/n/370163/viewer

Blue, G. M., \& Harun, M.(2003). Hospitality language as a professional skill. English for Specific Purposes,22, 73-91. https://doi.org/10.1016/S0889-4906(01)00031-X

Bobanovic, M. K., \& Grzinic, J. (2011). The importance of English language skills in the tourism sector: A comparative study of students'/employees' perceptions in Croatia. Almatourism Journal of Tourism, Culture and Territorial Development,2, 10-23. https://almatourism.unibo.it/article/view/2476/1849

Brown, J. D.(2009). Foreign and second language needs analysis. In H. Michael \& J. D. Catherine (Eds.), The handbook of language teaching (pp. 269-293). Wiley-Blackwell. https://www.wiley.com/en-us/The+Handbook+of+Language+Teaching-p9781405154895

Cohen, A., \& Macaro, E. (2007). Language learning strategies. Oxford University Press.

Crystal, D. (2003). English as a global language. Ernst Klett Sprachen.

Davies, J. (2000). A study of language skills in the leisure and tourism industry. Language Learning Journal, 21(1), 66-71. https://doi.org/10.1080/09571730085200131

Dhiman, M. C. (2012). Employers' perceptions about tourism management employability skills. Anatolia, 23, 359-72. https:// doi.org/10.1080/13032917.2012.711249

Dudley-Evans, T., \& St. John, M. J. (1998). Developments in English for Specific Purposes. Cambridge University Press.

Flowerdew, L. (2013). Needs analysis and curriculum development in ESP. In P. Brian \& S. Starfield (Eds.), The handbook of English for specific purposes (pp. 325-345). WileyBlackwell. https://doi.org/10.1002/9781118339855.ch17

Fujita, R. (2020). English for tourism and hospitality. In H. Terauchi, J. Noguchi \& A. Tajino (Eds.),Towards a new paradigm for English language teaching: English for specific purposes in Asia and beyond (pp.172-180). Routledge.

Gonzalez-Pastor, D. M. (2013). Developing intercultural competence in English for the tourism classroom through the study of cultural words. Teaching Foreign Languages for Tourism: Research and Practice, 17, 107-126. https://www.academia.edu/28576137/Developing_intercultural_competence_in_th e_English_for_Tourism_classroom_through_the_study_of_cultural_words

Horwitz, E. K. (2012). Becoming a language teacher: A practical guide to second language learning and teaching $\left(2^{\text {nd }}\right.$ ed.). Pearson Education. 
Hutchinson, T., \& Waters, A. (1987). English for specific purposes. Cambridge University Press.

Javid, C. Z., \& Khan, U. M. (2013). Investigating English language needs: Medical undergraduates' perspective in a Saudi context. Pakistan Journal of Social Sciences (PJSS), $33(2)$,

363-377.

http://www.bzu.edu.pk/PJSS/Vol33No22013/PJSS_Vol33\%20No\%202_2013_12.pdf

Javid, C. Z., Al-Asmari, A., \& Farooq, M. U. (2012). Saudi undergraduates' motivational orientations towards English language learning along gender and university major lines: A comparative study. European Journal of Social Sciences, 27(2), 283-300. http://www.europeanjournalofsocialsciences.com/issues/EJSS_27_2.html

Kane, F., \& Al-Khudair, D. (October 13, 2021). Six giga-projects that epitomize Saudi Arabia $\$ 7$ trillion development plan. Arab News. Retrieved from https://www.arabnews.com/node/1947546/saudi-arabia

Khan, T. M., Ghulamullah, Mohsin, M. N.,Dogar, A. H., \& Awan, A. S. (2011). Needs analysis of English for Occupational and Specific Purposes. International Journal of Social $\begin{array}{llll}\text { Sciences } & \mathcal{E} & \text { Education, } & \text { 632-643. }\end{array}$ http:/ /ijsse.com/sites/default/files/issues/2011/v1i4/paper\%2026/paper\%2026.pd $\mathrm{f}$

Kim, H. H. (2013). Needs analysis for English for specific purpose course development for engineering students in Korea. International Journal of Multimedia \& Ubiquitous Engineering, 8(6), 279-288. https://doi.org/10.14257/ijmue.2013.8.6.28

Kim, N., Park, J. \& Choi, J. (2017). Perceptual differences in core competencies between tourism industry practitioners and students using analytic hierarchy process (AHP). Journal of Hospitality, Leisure, Sport $\mathcal{E}$ Tourism Education, 20, 76-86. https://doi.org/10.1016/j.jhlste.2017.04.003

Liu, D., \& Zhang, P. (2020). A needs analysis proposal for ESP: A case study of a short English training course for bank tellers in a Chinese bank. Open Journal of Social Sciences, 8, 206-217.

DOI:

$10.4236 /$ jss.2020.87017. https:/ / www.scirp.org/journal/paperinformation.aspx?paperid=101616

Maswana, S., \& Tajino, A. (2020). ESP curriculum development: A systems approach. In T. Hajime, N. Judy \& A. Tajino (Eds.), Towards a new paradigm for English language teaching: Englush for specific purposes in Asia and beyond (pp.66-76). Routledge.

Mohammadi, V., \& Mousavi, N. (2013). Analyzing needs analysis in ESP: A (re) modeling. International Research Journal of Applied and Basic Sciences, 4(5), 1014-1020. https://irjabs.com/files_site/paperlist/r_786_130511111853.pdf

Prachanant, N. (2012). Needs analysis on English language use in tourism industry. Procedia Social and Behavioral Sciences,66, 117-25. https:/ / doi.org/10.1016/j.sbspro.2012.11.253

Rahim, S. A., \& Tazijan, F. (2011). Analyzing the Training and Internship Needs Assessment of Verbal Communication Skills amongst Hotel Practitioners. English Language Teaching,4, 44-53. https://www.ccsenet.org/journal/index.php/elt/article/view/11874

Rostami, F., \& Zafarghandi, A. M. (2014). EAP needs analysis in Iran: The case of university students in chemistry department. Journal of Language Teaching $\mathcal{E}$ Research, 5(4), 924934. http://www.academypublication.com/issues/past/jltr/vol05/04/25.pdf

Shing, S. R., \& Sim, T. S. (2011). EAP needs analysis in higher education: Significance and future direction. English for Specific Purposes World,33, 1-11. http://espworld.info/articles_33/doc/eap\%20needs\%20analysis\%20in\%20higher\%20education _shing.pdf

Songhori, M. H. (2008). Introduction to needs analysis. English for Specific Purposes World,4, 1-25. https://www.academia.edu/5774069/English_for_Specific_Purposes_world_Issue_4 _2008_www_esp_world_info_Introduction_to_Needs_Analysis_Introduction_to_Nee ds_Analysis_By_Mehdi_Haseli_Songhori_Introduction 
Swales, J. (1990). Genre analysis: English in academic and research settings. Cambridge University Press.

West, R. (1994). Needs analysis in language teaching. Language Teaching, 27(1), 1-19. https://toaz.info/doc-viewer

Wolrd Tourism Orgnization. (2020). Regional report on women in tourism in the Middle East. https://www.e-unwto.org/doi/pdf/10.18111/9789284422371

Yasmin, M., Sarkar, M., \& Sohail, A. (2016). Exploring English language needs in the hotel industry in Pakistan: An evaluation of existing teaching material. Journal of Hospitality E Tourism Education, 28, 202-13. https://doi.org/10.1080/10963758.2016.1226846

Yundayani, A. (2018). Present situation analysis: Students' early characteristics in writing for academic purposes. English Review: Journal of English Education, 6(2), 119-126. https://journal.uniku.ac.id/index.php/ERJEE/article/view/1262 